\title{
The Role Of Laboratory In The Efforts Of Increasing Vocational Education QUALITY IN INDUSTRIAL REVOLUTION 4.0
}

\section{Perananan laboratorium Dalam Upaya Peningkatan Mutu Pendidikan Kejuruan Di Era REVOLUSI INDUSTRI 4.0}

\author{
Muhammad Hudan Rahmat ${ }^{1)}$, Marko Ayaki Lumbantobing ${ }^{2)}$ \\ 1), Program Studi Pendidikan Teknik Mesin, FKIP, UPR \\ 2), Program Studi Pendidikan Teknik Mesin, FKIP, UPR \\ Kampus Unpar Tunjung Nyaho, Jl. H. Timang, 73111A \\ e-mail: hudanrahmat@fkip.upr.ac.id
}

\begin{abstract}
The competition of working world in the industrial revolution era 4.0 requires many countries to improve themselves in producing the quality of human resources. Therefore, vocational education institutions as producers of workforce that ready to work have to produce the top notch output. This demand have to be immediately reflected and implemented in formal education and training programs. By the existence of laboratory, students are able to do anything to learn and practice their skills due to the characteristics of vocational education are more underlined in the development of learners' psychomotor aspects. Hence, the existence of laboratory has a crucial role for vocational education in order to enhance the quality of vocational education thus the improvement of vocational program quality for final graduates are achieved greatly.
\end{abstract}

\section{Keywords: Laboratory, Quality of Vocational Education, Industrial Revolution 4.0}

Persaingan dalam dunia kerja pada era revolusi industri 4.0 menuntut banyak negara untuk berbenah diri dalam menghasilkan sumber daya manusia yang berkualitas. Untuk itu lembaga pendidikan kejuruan sebagai pencetak tenaga kerja yang siap kerja harus menghasilkan output yang bemutu. Tuntutan ini harus segera direfleksikan dan diimplementasikan dalam program-program pendidikan dan pelatihan praktis. Dengan adanya laboratorium, peserta didik dapat melakukan hal-hal apa saja untuk belajar dan melatih keterampilan, dikarenakan karakteristik pendidikan kejuruan lebih menonjolkan terhadap pengembangan aspek psikomotrik peserta didik. Untuk itu keberadaan laboratorium memiliki peranan penting bagi pendidikan kejuruan dalam rangka meningkatkan mutu pendidikan kejuruan agar terwujudnya tujuan meningkatkan kualitas sumber daya lulusannya.

Kata Kunci: Laboratorium, Mutu Pendidikan Kejuruan, Revolusi Industri 4.0

\section{PENDAHULUAN}

Era revolusi industri 4.0 mengubah konsep pekerjaan, struktur pekerjaan, dan kompetensi yang dibutuhkan dunia pekerjaan. Sebuah survei perusahaan perekrutan internasional, Robert Walters, bertajuk Salary Survey 2018 menyebutkan, fokus pada transformasi bisnis ke platform digital telah memicu permintaan profesional sumber daya manusia (SDM) yang memiliki kompetensi yang jauh berbeda dari sebelumnya. Era revolusi industri 4.0 juga mengubah cara pandang tentang pendidikan (Sukartono, 2018).

Perubahan yang dilakukan tidak hanya sekadar cara mengajar, tetapi jauh yang lebih esensial, yakni perubahan cara pandang terhadap konsep pendidikan itu sendiri.

Menghadapi revolusi industri 4.0 tentu bukan hal mudah, sehingga mempersiapkan hal-hal yang terkait dengan hal tersebut menjadi suatu keharusan. Menurut Zubaidah (2018) salah satu elemen penting yang harus menjadi perhatian untuk mendorong pertumbuhan ekonomi dan daya saing bangsa di era revolusi industri 4.0 adalah mempersiapkan sistem pembelajaran yang lebih inovatif, dan meningkatkan kompetensi lulusan yang memiliki keterampilan abad ke-21. Oleh karena trend di abad 21 lebih berfokus pada spesialisasi tertentu, maka tujuan pendidikan harus diarahkan pada upaya membentuk keterampilan dan sikap individu abad 21 .

Pendidikan kejuruan di Indonesia bertugas untuk meyiapkan tenaga kerja yang sesuai dengan kebututuhan dunia kerja. Peningkatan mutu pendidikan kejuruan dalam era revolusi industri 4.0 harus mendapat perhatian khusus agar lembaga pendidikan ini tidak terpuruk dan tertinggal akibat cepatnya perubahan dan perkembangan teknologi yang terjadi. Keberhasilan suatu lembaga pendidikan kejuruan dilihat dari indikator lulusannya, ditentukan oleh mutu sumber daya manusia, sarana dan prasarana pendukung serta manajemen lembaga pendidikan tersebut. 
Laboratorium merupakan salah satu komponen prasarana dalam melaksanakan proses belajar mengajar yang efektif yang urgensinya sangat dominan dalam upaya meningkatkan mutu pembelajaran dan mutu pendidikan pada umumnya yang pada akhirnya bermuara pada peningkatan mutu lulusan yang optimal. Dengan adanya laboratorium, kegiatan pelatihan di lembaga pendidikan kejuruan menjadi lebih efektif sehingga menunjang dalam pencapaian kompetensi produktif.

Menurut situs Litbang Kementrian Pendidikan dan Kebudayaan RI dinyatakan bahwa setiap satuan pendidikan wajib memiliki sarana dan prasarana. Perinciannya adalah sebagai berikut: (1) Setiap satuan pendidikan wajib memiliki sarana yang meliputi perabotan, peralatan pendidikan, media pendidikan, buku dan sumber belajar lainnya, bahan habis pakai, serta perlengkapan lain yang diperlukan untuk menunjang proses pembelajaran yang teratur dan berkelanjutan; (2) Setiap satuan pendidikan wajib memiliki prasarana yang meliputi lahan, ruang kelas, ruang pimpinan satuan pendidikan, ruang pendidik, ruang tata usaha, ruang perpustakaan, ruang laboratorium, ruang bengkel kerja, ruang unit produksi, ruang kantin, instalasi daya dan jasa, tempat berolahraga, tempat beribadah, tempat bermain, tempat berkreasi, dan ruang/tempat lain yang diperlukan untuk menunjang proses pembelajaran yang teratur dan berkelanjutan.

Lebih lanjut laporan Bank Dunia menyebutkan bahwa dalam upaya peningkatan kualitas pendidikan di Indonesia akan sangat dipengaruhi oleh lima faktor dominan yaitu: penerapan dan pengembangan kurikulum, kualitas pendidik dan bahan ajar, sistem tes, efektivitas pelatihan dan lingkungan sekolah yang kondusif (The World Bank, 1997). Berpijak dari hal tersebut dapat diartikan bahwa laboratorium merupakan salah satu faktor penunjang dalam meningkatkan kualitas pendidikan kejuruan di Indonesia, dengan adanya laboratorium kegiatan pelatihan di lembaga pendidikan menjadi lebih efektif sehingga menunjang dalam pencapaian kompetensi produktif.

Suksesnya pengembangan suatu lembaga pendidikan khususnya pendidikan kejuruan terletak pada pencapaian kompetensi yang berupa pengetahuan sikap, dan keterampilan. Oleh karena itu proses yang terpenting dalam pendidikannnya adalah belajar dan latihan, belajar sifatnya interaktif dan terjalin dalam setiap proses. Melalui pendidikan di sekolah setiap siswa dapat belajar dan berlatih, dengan belajar dan berlatih maka siswa akan menguasai kompetensi tertentu, sehingga siswa dapat berkarya atau memberikan jasa dan dapat memperoleh penghasilan untuk memenuhi kebutuhan hidupnya yang senantiasa berkembang. Untuk itu dalam tulisan ini akan dibahas mengenai peranan laboratorium sebagai upaya peningkatan mutu pendidikan kejuruan di era Revolusi Industri 4.0.

\section{PEMBAHASAN}

\section{Karakteristik Era Revolusi Industri 4.0}

Industrialisasi dunia dimulai pada akhir abad ke-18 dengan munculnya tenaga uap dan penemuan kekuatan alat tenun, secara radikal mengubah bagaimana barangbarang diproduksi, masa ini disebut sebagai revolusi industri 1.0. Seabad kemudian, listrik dan jalur perakitan memungkinkan produksi massal, atau disebut revolusi industri 2.0. Pada 1970-an, revolusi industri 3.0 dimulai ketika kemajuan dalam otomatisasi bertenaga komputer memungkinkan seseorang memprogram mesin dan jaringan (Sukartono, 2018). Industri 4.0 selanjutnya hadir menggantikan industri 3.0 yang ditandai dengan cyber fisik dan kolaborasi manufaktur (Hermann et al, 2015; Irianto, 2017). Istilah industri 4.0 berasal dari sebuah proyek yang diprakarsai oleh pemerintah Jerman untuk mempromosikan komputerisasi manufaktur.

Karakteristik era revolusi industri 4.0 menurut pendapat para ahli yang disampaikan Kemristekdikti (2018) ditandai dengan adanya: (1) $75 \%$ pekerjaan melibatkan kemampuan sains, teknologi, teknik dan matematika, internet of things (IoT), pembelajaran sepanjang hayat; (2) disebut sebagai industri berbasis Cyber Physical System, gabungan antara domain digital, fisik, dan biologi; (3) lebih dari $55 \%$ organisasi menyatakan bahwa digital talent gap semakin lebar; (4) perlunya peningkatkan kualitas keterampilan tenaga kerja dengan teknologi digital; (5) semakin pentingnya kecakapan sosial (social skills) dalam bekerja.

Abad ke-21 ditandai dengan era revolusi industri 4.0 sebagai abad keterbukaan atau abad globalisasi, artinya kehidupan manusia pada abad ke-21 mengalami perubahan-perubahan yang fundamental yang berbeda dengan tata kehidupan dalam abad sebelumnya. Dengan sendirinya abad ke-21 meminta sumberdaya manusia yang berkualitas, yang dihasilkan oleh lembaga-lembaga yang dikelola secara profesional sehingga membuahkan hasil unggulan. Tuntutan-tuntutan yang serba baru tersebut meminta berbagai terobosan dalam berfikir, penyusunan konsep, dan tindakan-tindakan. Dengan kata lain diperlukan suatu paradigma baru dalam menghadapi tantangan-tantangan yang baru. Tantangan yang baru menuntut proses terobosan pemikiran (breakthrough thinking process) apabila yang diinginkan adalah output yang bermutu yang dapat bersaing dengan hasil karya dalam dunia yang serba terbuka (Tilaar dalam Sukartono, 2018).

\section{Mutu Pendidikan Kejuruan}

Sistem pendidikan sekolah harus bersifat terbuka dan memberikan kemungkinan kepada siapa saja memasuki Pendidikan Tinggi, asalkan memenuhi syaratsyarat yang ditetapkan. Dalam syarat itu faktor pengalaman bekerja tidak dapat diabaikan dan harus pula diperhitungkan sebagai faktor yang meningkatkan 
kemampuan orang tersebut. Maka tidak benar untuk menganggap pendidikan kejuruan lebih rendah dari pendidikan akademis. Yang benar adalah bahwa setiap pendidikan mempunyai fungsinya sendiri bagi kehidupan bangsa. Jelas bahwa bangsa Indonesia sangat memerlukan pendidikan kejuruan yang luas dan bermutu agar dapat mengembangkan daya saing tinggi dalam era globalisasi.

Istilah mutu mengandung banyak pengertian dan penafsiran, ada yang berpendapat bahwa mutu atau kualitas adalah sesuatu yang baik, dan ada yang berpendapat bahwa mutu adalah sesuatu yang sesuai dengan kebutuhan yang diharapkan. Secara umum dapat dikatakan bahwa mutu adalah kesesuaian dengan standar. Sedangkan pengertian standar sendiri dapat dibedakan dalam satu rentangan dengan ambang batas minimal atau standar minimal pada awal dan standar target pada ujung rentangan yang lain.

Konsep tentang mutu pendidikan diartikan secara berbeda-beda, tergantung pada situasi, kondisi dan sudut pandang. Perbedaan sudut pandang dikarenakan dalam proses pendidikan ada tiga unsur yang berkepentingan, yaitu pemerintah dan/atau yayasan bagi pendidikan swasta yang menentukan aturan pengelolaan, peserta didik/orangtua yang memperoleh manfaat dari hasil pendidikan dan masyarakat pengguna (stakeholder) yang memperoleh manfaat dari tersedianya tenaga terdidik. Ketiga sudut pandang ini ada kemungkinan berbeda dalam mengartikan mutu proses pendidikan. Ada yang berpendapat bahwa mutu pendidikan ditandai dengan kesesuaian dengan kondisi dan kebutuhan, daya tarik pendidikan yang besar, efektivitas program, sarana dan prasarana yang menunjang. Sementara itu masyarakat umum berpendapat bahwa ukuran mutu yang utama adalah besarnya keterserapan lulusan sekolah pada lapangan kerja.

Acuan mutu pendidikan kejuruan di Indonesia yaitu berdasarkan Standar Pelayanan Minimal, Standar Nasional Pendidikan dan SNP+X. Terdapat delapan standar nasional pendidikan dalam Peraturan Pemerintah Nomor 19 tahun 2005 tentang Standar Nasional Pendidikan ini telah menjadi aturan minimal yang harus dicapai oleh sekolah. Delapan standar nasional pendidikan itu meliputi: (1) Standar isi, (2) Standar proses, (3) Standar kompetensi lulusan, (4) Standar pendidik dan tenaga kependidikan, (5) Standar sarana dan prasarana, (6) Standar pengelolaan, (7) Standar pembiayaan, (8) Standar penilaian pendidikan.

Upaya peningkatan mutu pendidikan juga terus dilakukan dengan penataan kelembagaan akreditasi menjadi suatu lembaga yang independen dengan melakukan peningkatan kualitas pengelolaan akreditasi program studi, peningkatan kinerja proses akreditasi, serta peningkatan kesiapan lembaga yang membutuhkan akreditasi dan tindak lanjut hasil akreditasi. Hal terpenting dalam penyelenggaraan pendidikan adalah peningkatan dan penjaminan mutu pendidikan. Penjaminan dan peningkatan mutu pendidikan dilakukan untuk menjawab daya saing, pencitraan terhadap masyarakat, serta akuntabilitas pendidikan (Susilo dkk., 2016).

Pengajaran teknik atau teknologi kejuruan memiliki ciri khas yang menekankan proses belajar pembelajaran untuk tujuan kognitif, psikomotorik, dan afektif. Tujuan kognitif diasosiasikan dengan tujuan kinerja verbal, tujuan afektif ditujukan untuk kinerja sikap, sedangkan tujuan psikomotorik ditujukan untuk dapat membuat identifikasi fisik, melakukan tindakan fisik sederhana, melakukan tindakan fisik kompleks, melakukan tindakan keterampilan fisik, melakukan tindakan keterampilan yang tepat untuk memecahkan masalah, dan menentukan kualitas produk fisik yang layak. Pada prakteknya ketiga tujuan kinerja tersebut diatas saling terkait, saling mendukung dan tidak dapat dipisahkan. Ketika teknologi berkembang pesat dan menjadi semakin kompleks, para ahli teknik dan teknisi harus lebih terlatih. Tuntutan ini lebih harus segera direfleksikan dalam dalam programprogram pendidikan dan pelatihan praktis. Lembaga Pendidikan kejuruan harus dapat dengan cepat menangkap dan memberi respon terhadap perkembangan teknologi dan permintaaan pasar.

\section{Perananan Laboratorium dalam Upaya Peningkatan Mutu Pendidikan di Era Revolusi Industri 4.0}

Ruang laboratorium adalah ruang untuk pembelajaran secara praktik yang memerlukan peralatan khusus (Permendiknas Nomor 40 Tahun 2008). Tujuan atau peranan laboratorium menurut DEPDIKBUD (1979:7) dijelaskan bahwa laboratorium berfungsi sebagai tempat untuk memecahkan masalah, mendalami suatu fakta, melatih keterampilan dan berfikir ilmiah, menanamkan dan mengembangkan sikap ilmiah, menemukan masalah baru, dan sebagainya. Menurut Daryani (2008:1) dalam proses pembelajaran, laboratorium mempunyai peranan yaitu sebagai tempat: (1) siswa dan guru dalam menyampaikan konsep berbasis pada penyelidikan, penemuan dan percobaan; (2) siswa dan guru dalam mengaitkan konsep yang dibahas dengan kehidupan sehari-hari; (3) guru memberi tugas yang berorientasi pada pengelompokan siswa; dan (4) siswa dan guru menciptakan model-model pembelajaran untuk memperkuat pemahaman konsep.

Secara garis besar fungsi laboratorium adalah sebagai berikut: (1) memberikan kelengkapan bagi pelajaran teori yang telah diterima sehingga antara teori dan praktek bukan merupakan dua hal yang terpisah, melainkan dua hal yang merupakan suatu kesatuan. keduanya saling mengkaji dan saling mencari dasar, (2) memberikan keterampilan kerja ilmiah bagi mahasiswa, (3) memberikan dan memupuk keberanian untuk mencari hakekat kebenaran ilmiah dari sesuatu obyek dalam lingkungan alam dan lingkungan sosial, (4) menambah keterampilan dalam mempergunakan alat media yang tersedia untuk mencari dan menentukan kebenaran, (5) memupuk rasa ingin tahu mahasiswa sebagai modal sikap ilmiah seseorang calon ilmuwan, (6) memupuk dan membina rasa percaya diri sebagai keterampilan yang 
diperoleh, penemuan yang didapat dalam proses kegiatan kerja di laboratorium.

Manfaat dari kegiatan di laboratorium antara lain adalah: (1) melatih siswa agar terampil dalam melakukan kegiatan praktik keterampilan teknik untuk berbagai sub bidang keterampilan, (2) merakit dan memasang alat/perlengkapan laboratorium keterampilan teknik, (3) melakukan aktivitas percobaan guna mengecek, uji coba, dan meneliti alat-alat laboratorium keterampilan teknik, ketetapan-ketetapan serta standardisasi yang telah dibuat, (3) membentuk dan mendesain komponenkomponen tertentu dalam berbagai keahlian dengan menggunakan fasilitas laboratorium keterampilan teknik, (4) melayani mahasiswa dan masyarakat dalam melakukan praktek kependidikan melalui alat-alat laboratorium keterampilan teknik sebagai media, dan (5) merawat dan memperbaiki alat/perlengkapan laboratorium keterampilan teknik. Fungsi tersebut dapat terwujud dengan baik apabila laboratorium sebagai sumber belajar kondisinya standar dan pendidik mampu menggunakan dan mengelola, serta mengembangkan laboratorium dalam rangka proses balajar-mengajar.

Peranan laboratorium, seperti yang tercantum dalam Peraturan Pemerintah No.5 tahun 1990 pasal 27, adalah sebagai sarana penunjang pembelajaran IPTEK tertentu sesuai program studi yang bersangkutan. Laboratorium merupakan tempat pengamatan, percobaan, latihan dan pengujian bidang teknologi dan kejuruan. Dengan demikian, keberadaan laboratorium dapat digunakan sebagai salah satu tolok ukur kemajuan suatu lembaga pendidikan.

Pengembangan laboratorium untuk dapat memenuhi Standar Minimal Laboratorium (SML) adalah mutlak dan tidak dapat ditawar lagi. Hal tersebut dilakukan dalam rangka mengantisipasi perkembangan iptek yang sangat pesat di dunia industri yang relatif lebih cepat daripada di lingkungan pendidikan. Melalui laboratorium pengetahuan digali, diperoleh harus ditransmisikan supaya dapat dipelihara kelangsungan eksistensinya, sehingga dalam penyelenggaraannya, pendidikan kejuruan harus memperhatikan penekanan psikomotorik, yang sesuai dengan perkembangan teknologi, dan berorientasi pada bidang pekerjaan tertentu.

Peran laboratorium dalam SMK ini pada dasarnya mendukung tercapainya tujuan pendidikan kejuruan, yaitu untuk membekali lulusannya dengan keterampilan tertentu. Ketersediaan sarana/fasilitas/peralatan sekolah, termasuk laboratorium, merupakan salah satu aspek utama indikator kinerja kunci dalam penyusunan portofolio institusi yang akan dinilai oleh Badan Akreditasi Nasional Sekolah/Madrasah (BAN-S/M). Untuk memenuhi standar kinerja normatif, ketersediaan sarana/fasilitas/peralatan yang ada harus diarahkan pada pencapaian visi, misi, dan tujuan institusi, serta kelayakan dan kesesuaian sarana untuk mendukung dan memiliki akses yang tinggi pada kegiatan belajar.

Untuk itu keperluan masa depan bangsa, SMK mempunyai peran yang amat penting. Adanya pendidikan kejuruan sangat berpengaruh terhadap produksi nasional dan daya saing Indonesia di dunia internasional. Namun penyelenggaraan SMK memerlukan investasi dan biaya operasi yang tidak sedikit untuk pengembangan sebuah laboratorium/ workshop yang mempunyai peralatan pratikum memadai.

\section{PENUTUP}

Terdapat tiga unsur yang berkepentingan terhadap kemajuan teknologi, yaitu pemerintah yang menentukan aturan pengelolaan, peserta didik/orangtua yang memperoleh manfaat dari hasil pendidikan dan masyarakat pengguna (stakeholder) yang memperoleh manfaat dari tersedianya tenaga terdidik mengantisipasi perkembangan iptek. Dalam upaya memenuhi kebutuhan industri terhadap tenaga kerja terampil, pendidikan kejuruan memiliki peranan penting untuk mencetak tenaga kerja yang dapat diandalkan di masa kini. Agar dalam pelaksanaan pembelajaran dapat optimal maka diperlukan sebuah laboratorium yang memadai sehingga dapat menunjang tercapainya visi misi dari pendidikan kejuruan dan mampu menghadapi persaingan di era revolusi industri ini.

\section{DAFTAR PUSTAKA}

[1]. Departemen Pendidikan Nasional. 2004. Standar Minimal Laboratorium, Workshop dan Studio Pendidikan Teknologi dan Kejuruan Jenjang S1, Direkrorat Jendral Pendidikan Tinggi, Jakarta.

[2]. Depdikbud. 1997. Keterampilan Menjelang 2020 untuk Era Global (laporan satuan tugas pengembangan Pendidikan dan Pelatihan Kejuruan di Indonesia, Depdikbud, Jakarta.

[3]. Direktorat Jendral Pendidikan Tinggi. 2005. Pelatihan Manajemen Pengelolaan Laboratorium Perguruan Tinggi Negeri, Makassar 14-16 Juni 2005. (BAN-PT, 2001).

[4]. Hermann, M., Pentek, T., \& Otto, B. 2016. Design Principles for Industrie 4.0 Scenarios. Presented at the 49th Hawaiian International Conference on Systems Science.

[5]. Irianto, D. 2017. Industry 4.0; The Challenges of Tomorrow. Disampaikan pada Seminar Nasional Teknik Industri, Batu-Malang.

[6]. Kemdikbud. 2013. Standar Sarana dan Prasarana. Jakarta. Litbang.

[7]. Kementerian Riset, Teknologi dan Pendidikan Tinggi. 2018. Mempersiapkan SDM Indonesia di Era Industri 4.0.

[8]. Peraturan Menteri Pendidikan Nasional Republik Indonesia Nomor 40 Tahun 2008 Tentang Standar 
Sarana dan Prasarana untuk Sekolah Menengah Kejuruan/ Madrasah Aliyah Kejuruan (SMK/MAK).

[9]. Peraturan Pemerintah Republik Indonesia No. 60 Tahun 1999 tentang Pendidikan Tinggi. Jakarta: Sekretariat Negara RI.

[10].Sukartono. 2017. Revolusi Industri 4.0 dan Dampaknya terhadap Pendidikan di Indonesia.

[11]. Susilo, Purnomo Hadi dkk. 2016. Sistem Manajemen Mutu ISO 9001:2008 Digital Berbasis Web Di SMK Widyagama Malang, Jurnal Pendidikan: Teori, Penelitian, dan Pengembangan Volume: 1 Nomor: 5 Mei 2016 Halaman: 971-977.
[12]. The World Bank. 1997. Vocational and Technical Education and Training. Washington, D.C., The World Bank.

[13]. Zubaidah, S. 2018. Mengenal 4c: Learning And Innovation Skills Untuk Menghadapi Era Revolusi Industri 4.0. Makalah Disampaikan pada Seminar " $2^{\text {nd }}$ Science Education National Conference" di Universitas Trunojoyo Madura, 13 Oktober 2018. 